Mata Kuliah : : Pendidikan Matematika II

Dosen Pengampu : Jusmawati,S.Pd.,M.Pd

\title{
PENDIDIKAN MATEMATIKA ll
}

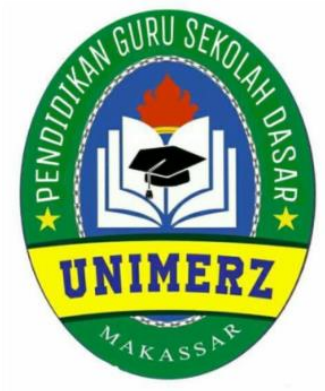

DISUSUN OLEH :

SRI DEWI CAHYANI (C1C119011)

PROGRAM SARJANA PENDIDIKAN GURU SEKOLAH DASAR FAKULTAS KEGURUAN DAN ILMU PENDIDIKAN

UNIVERSITAS MEGAREZKY 


\section{KATA PENGANTAR}

Puji syukur kehadirat Allah SWT yang telah memberikan rahmat dan karunia-Nya sehingga kami dapat menyelesaikan makalah yang berisikan tentang "Pecahan, Bangun Datar Pada Bagian Lingkaran, dan Bangun Ruang Pada Bagian Tabung tepat pada waktunya".

Makalah ini diharapkan dapat bermanfaat untuk menambah pengetahuan bagi para pembaca dan dapat digunakan sebagai salah satu pedoman dalam proses pembelajaran.

Kami menyadari bahwa makalah ini masih banyak kekurangan karena pengetahuan yang kami miliki cukup terbatas. Oleh karena itu, kami berharap kritik dan saran dari pembaca yang bersifat membangun untuk kesempurnaan makalah ini.

Makassar, 10 Februari 2022

Penulis 


\section{DAFTAR ISI}

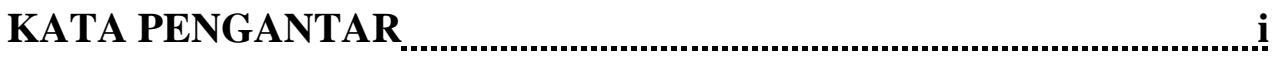

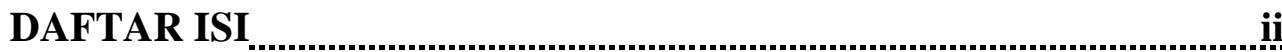

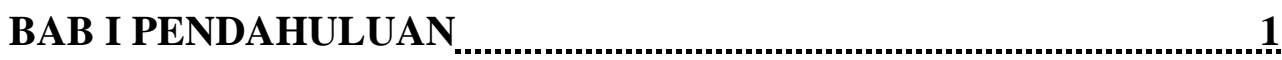

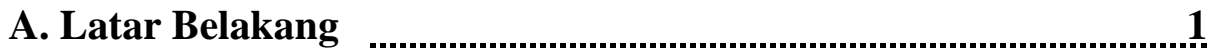

B. Rumusan Masalah ..................................................................

C. Tujuan

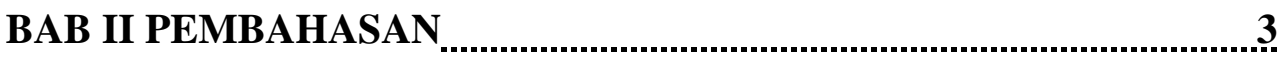

A. Bilangan Pecahan

B. Bangun Datar Pada Lingkaran ..................................................

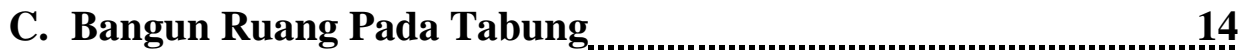

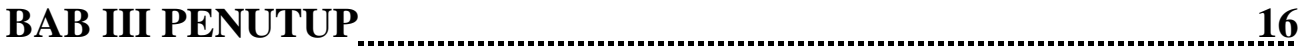

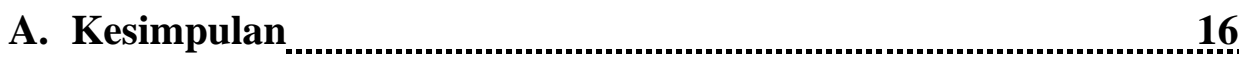

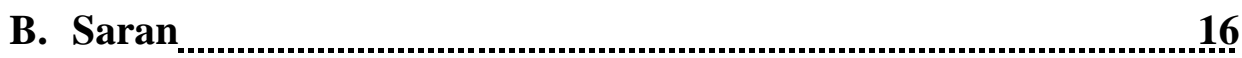

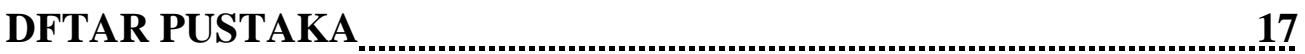




\section{BAB I}

\section{PENDAHULUAN}

\section{A. Latar Belakang}

Salah satu upaya untuk meningkatkan pemahaman ilmu dan teknologi yaitu melalu pemahaman berbagai macam ilmu pengetahuan secara interdisiplin. Ilmu matematika besar sekali manfaatnya di dalam memahami ilmu dan teknologi sekaligus. Dalam memahami ilmu matematika disebutkan batas usia. Hal ini berarti pemahaman ilmu matematika dapat dimulai sejak dini. Matematika sebagai salah satu ilmu pengetahuan merupakan salah satu sarana untuk meningkatkan kemampuan berpikir setiap orang, oleh karena itu kesadaran untuk mampu mengetahui dan memahami matematika bagi siswa sangat diharapkan sudah bertumbuh sejak usia dini. Membentuk pemahaman yang utuh pada anak dalam pelajaran matematika diperlukan kecintaan terlebih dahulu terhadap matematika.

Pecahan merupakan salah satu kajian inti dari materi matematika sekolah dasar, materi ini mempelajari dasar dari pecahan agar peserta didik mudah untuk memahami materi pecahan untuk tingkat lanjut. Pembahasan pada materi pecahan menitik beratkan pada pengajaran hitung dasar seperti penjumlahan, pengurangan, perkalian dan pembagian baik untuk pecahan sederhana maupun campuran.

Pada materi pecahan di sekolah dasar, konsep pecahan merupakan konsep yang penting untuk dipahami dan dikuasai peserta didik. Pembelajaran secara singkat berdampak pada peserta didik karena sulit untuk memahami dan menguasai materi pecahan. Dan pembelajaran secara mekanistik berdampak pada ketidakbermaknaan proses belajar peserta didik karena matematika disajikan terpisah dari konteks yang bisa dipahami peserta didik pada awal pembelajaran. Sehingga konsep matematika akan mudah dilupakan dan sulit untuk menerapkan materi pecahan. 


\section{B. Rumusan Masalah}

1. Apa pengertian dan bagaimana itu bilangan pecahan?

2. Apa pengertian dan bagaimana itu lingkaran?

3. Apa pengertian dan bagaimana itu tabung?

\section{Tujuan}

1. Untuk mengetahui apa pengertian dan bagaimana itu bilangan pecahan.

2. Untuk mengetahui apa pengertian dan bagaimana itu Lingkaran.

3. Untuk mengetahui apa pengertian dan bagaimana itu tabung. 


\section{BAB II}

\section{PEMBAHASAN}

\section{A. Pengertian Bilangan Pecahan}

Pecahan yaitu bagian dari yang utuh. Jika sebuah benda diabagi dua bagian sama besar, maka nilai setiap bagian adalah setengah dari utuh. Bilangan pecahan adalah bilangan yang terdiri dari pembilang dan penyebut yang menggambarkan bagian dari keseluruhan yang dilambangkan dengan $\frac{a}{b}$. Dalam hal ini $a$ disebut pembilang dan $\mathrm{b}$ disebut penyebut dengan $\mathrm{b}$ \# 0 . Pembilang terdiri dari bilangan bulat $(0,1,2,3 \ldots)$ dan penyebut terdiri dari bilangan asli $(1,2,3 \ldots)$.

Contoh:

$\frac{1}{2}$

Catatan : $1=$ Pembilang

$2=$ Penyebut

\section{Jenis-Jenis Bilangan Pecahan}

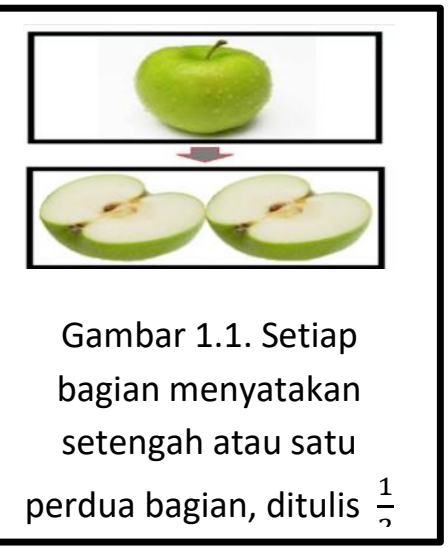

1. Pecahan Biasa

Bilangan pecahan yang hanya terdiri dari pembilang dan penyebut dinamanakan pecahan biasa. Pecahan biasa ada dua jenis yaitu :

a. Jika pembilang lebih kecil dari penyebutnya atau $(a<b)$ maka $\frac{a}{b}$ disebut pecahan murni

Contoh: $\frac{3}{2}, \frac{2}{3}, \frac{3}{4}, \frac{7}{8}$.

b. Jika pecahan yang pembilangnya lebih besar dari penyebutnya ( $a>$ b) maka $\frac{a}{b}$ disebut pecahan bukan murni

Contoh: $\frac{3}{2}, \frac{4}{3}, \frac{10}{7}, \frac{17}{9}$. 
2. Pecahan Campuran

Pecahan campuran adalah pecahan yang terdiri dari bilangan bulat dan bilangan pecahan. Bilangan pecahan campuran adalah bilangan dalam bentuk $a \frac{b}{c}$. Dalam hal ini, $a$ adalah bilangan bulat dan $\frac{b}{c}$ merupakan bilangan pecahan murni. Pecahan campuran dapat diubah menjadi pecahan biasa dengan membagi pembilang dan penyebutnya, begitupun sebaliknya pecahan biasa dapat diubah menjadi pecahan senilai jika bilangan pembilang lebih besar dari bilangan penyebutnya.

Contoh : $2 \frac{1}{2}, 8 \frac{3}{5}, 7 \frac{3}{4}, 1 \frac{7}{8}$.

3. Pecahan Desimal

Pecahan desimal adalah pecahan yang diperoleh dari hasil pembagian suatu bilangan terdiri atas dua angka atau lebih dan disertai tanda koma dengan bilangan pecahan per sepuluhan, per seratusan, per seribuan, dan seterusnya.

Contoh :

a. 2,7 dengan pengertian:

2 menunjukkan angka satuan dan 7 menunjukkan angka per sepuluhan

b. 1,35 dengan pengertian:

1 menunjukkan angka satuan, 3 merupakan angka satuan, 3 menunjukkan angka per sepuluhan, dan 5 menunjukkan angka per seratusan.

\section{Menyederhanakan Pecahan}

Menyederhanakan pecahan artinya mengubah pecahan tersebut menjadi pecahan senilai yang paling kecil. Caranya dengan membagi 
pembilang dan penyebutnya terhadap bilangan yang sama, yaitu FPB dari pembilang dan penyebut.

Bilangan pecahan dapat disederhanakan tanpa mengubah nilainya dengan cara :

a. Membagi pembilang dan penyebutnya dengan pembagi persekutuan terbesar (FPB)

b. Membagi pembilang dan penyebutnya dengan pembagi persekutuan secara berantai.

Contoh:

Tentukan bentuk yang paling sederhana dari pecahan $\frac{45}{54}$

Cara 1:

$$
\frac{2}{4}=\frac{2: 2}{4: 2}=\frac{1}{2}
$$

FPB dari 45 dan 54 adalah 9

$\frac{45}{54}=\frac{45: 9}{54: 9}=\frac{5}{6}$

Jadi bentuk yang paling sederhana dari $\frac{45}{54}$ adalah $\frac{5}{6}$.

Cara 2:

$\frac{45}{54}=\frac{45: 3}{54: 3} \cdot=\frac{15}{18}$

$\frac{15}{18}=\frac{15: 3}{18: 3}=\frac{5}{6}$

Jadi bentuk yang paling sederhana dari $\frac{45}{54}$ adalah $\frac{5}{6}$. 


\section{Mengurutkan Pecahan}

Hal-hal yang harus diperhatikan dalam mengurutkan pecahan adalah sebagai berikut :

1. Jika penyebutnya sama, urutkan pecahan-pecahan tersebut dari yang pembilangnya terkecil sampai dengan yang terbesar atau sebaliknya.

2. Jika penyebutnya tidak sama, samakan dahulu penyebut pecahanpecahan te rsebut dengan menggunakan KPK dari penyebut-penyebut tersebut. Setelah itu, urutkan pecahan-pecahan tersebut dari yang pembilangnya terkecil sampai dengan yang terbesar atau sebaliknya.

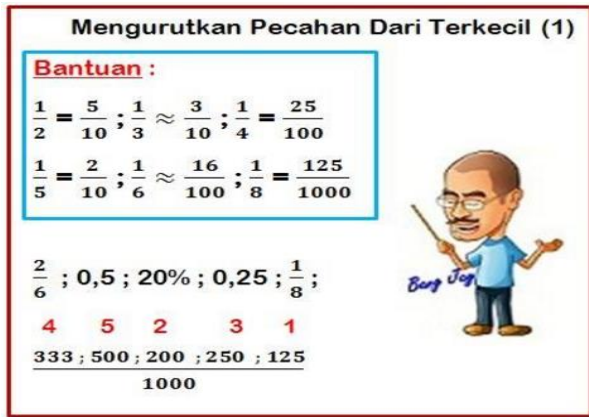

Contoh :

1. Urutkan pecahan $\frac{1}{6}, \frac{4}{6}, \frac{5}{6}, \frac{3}{6}, \frac{2}{6}$

Jawab:

Pecahan-pecahan itu memiliki penyebut yang sama yaitu 6, sehingga urutannya sebagai berikut.

Urutan pecahan dari yang terkecil : $\frac{1}{6}, \frac{2}{6}, \frac{3}{6}, \frac{4}{6}, \frac{5}{6}$

Urutan pecahan dari yang terbbesar: $\frac{5}{6}, \frac{4}{6}, \frac{3}{6}, \frac{2}{6}, \frac{1}{6}$

2. Urutkan pecahan $\frac{3}{4}, \frac{5}{6}, \frac{1}{2}, \frac{2}{3}$

Jawab:

KPK dari 4, 6, 2, dan 3 adalah 12
$\frac{3}{4}=\frac{9}{12}$
$\frac{1}{2}=\frac{6}{12}$
$\frac{5}{6}=\frac{10}{12}$
$\frac{2}{3}=\frac{8}{12}$ 
Urutan pecahan dari yang terkecil: $\frac{1}{2}, \frac{2}{3}, \frac{3}{4}, \frac{5}{6}$

Urutan pecahan dari yang terbesar: $\frac{5}{6}, \frac{3}{4}, \frac{2}{3}, \frac{1}{2}$

\section{Mengubah Bilangan Pecahan ke Pecahan Bentuk Lain}

1. Mengubah bentuk pecahan biasa ke bentuk pecahan campuran

Bilangan pecahan $\frac{a}{b}$ dengan $a \quad$ b dan $\mathrm{b} \# 0$ dapat diubah kedalam bentuk pecahan campuran $\mathrm{c} \frac{d}{b}$.

Contoh :

$\frac{4}{3}=\frac{3}{3}+\frac{1}{3}=1+\frac{1}{3}=1 \frac{1}{3}$

2. Mengubah bentuk pecahan campuran ke bentuk pecahan biasa

Pecahan campuran $a \frac{c}{d}$ dapat diubah kebentuk pecahan biasa, dengan cara :

$a \frac{c}{d}=\frac{a \times d+c}{d}$

Contoh :

$3 \frac{1}{2}=\frac{3 \times 2+1}{2}=\frac{6+1}{2}=\frac{7}{2}$

3. Mengubah bentuk pecahan biasa ke bentuk pecahan desimal

Bilangan pecahan $\frac{a}{b}$ dapat diubah menjadi bentuk pecahan desimal, dengan cara mengubah penyebut $b$ menjadi kelipatan sepuluh.

Contoh :

$\frac{3}{5}=\frac{3 \times 2}{5 \times 2}=\frac{6}{10}=0,6$ 
4. Mengubah bentuk pecahan desimal ke bentuk pecahan biasa

Bilangan pecahan desimal dapat diubah menjadi bentuk pecahan biasa, yaitu bentuk persepuluhan, perseratusan, perseribuan dan seterusnya.

Contoh :

$0,5=\frac{5}{10}=\frac{5: 5}{10: 5}=\frac{1}{2}$

5. Mengubah bentuk pecahan biasa ke bentuk pecahan persen

Bilangan pecahan $\frac{a}{b}$ dapat diubah menjadi bentuk persen dengan cara mengalikan bilangan tersebut dengan $100 \%$.

Contoh :

$\frac{4}{5}=\frac{4}{5} \times 100 \%=80 \%$

6. Mengubah bentuk persen ke bentuk pecahan biasa

Bilangan pecahan persen dapat diubah menjadi bentuk pecahan biasa, yaitu pecahan perseratusan.

Contoh :

$65 \%=\frac{65}{100}=\frac{65: 5}{100: 5}=\frac{13}{10}$

\section{Operasi Hitung Pada Bilangan Pecahan}

1. Penjumlahan pada bilangan pecahan

Dua bilangan pecahan dapat dijumlahkan jika memiliki penyebut yang sama. Jika penyebutnya berbeda maka harus disamakan terlebih dahulu, yaitu dengan cara mencari KPK dari kedua penyebut tersebut.

Dapat ditulis:

$\frac{a}{b}+\frac{c}{d}=\frac{a d}{b d}+\frac{b c}{b d}=\frac{a d+b c}{b d}$ 


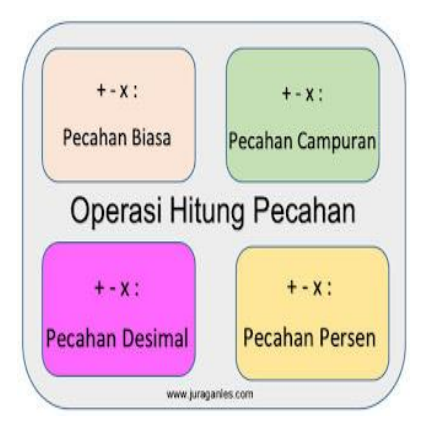

a. Penjumlahan dua pecahan berpenyebut sama

Penjumlahan pecahan yang memiliki penyebut sama, dilakukan dengan cara menjumlahkan pembilang-pembilangnya dengan penyebut tetap.

Contoh:

1) $\frac{3}{7}+\frac{2}{7}=\frac{3+2}{7}=\frac{5}{7}$

2) $\frac{3}{5}+2 \frac{1}{5}=2+\frac{3+1}{5}=2+\frac{4}{5}=2 \frac{4}{5}$

3) $4 \frac{1}{6}+1 \frac{4}{6}=(4+1)+\left(\frac{1}{6}+\frac{4}{6}\right)=5+\frac{5}{6}=5 \frac{5}{6}$

b. Penjumlahan dua pecahan berpenyebut tidak sama

Langkah pertama yang dilakukan adalah menyamakan penyebut-penyebutnya terlebih dahulu, yaitu dengan cara menentukan KPK-nya. Pembilang disesuaikan nilainya dengan cara mengalikan dengan KPK dari dua penyebut tadi. Selanjutnya, jumlahkan pembilang-pembilangnya dan penyebut tetap.

Contoh:

1) $\frac{2}{5}+\frac{1}{4}=\frac{8}{20}+\frac{5}{20}=\frac{3+5}{20}=\frac{13}{20}$

2) $2 \frac{3}{4}+\frac{1}{6}=2+\left(\frac{3}{4}+\frac{1}{6}\right)=2+\left(\frac{9}{12}+\frac{2}{12}\right)=2+\frac{11}{12}=2 \frac{11}{12}$

3) $3 \frac{2}{7}+2 \frac{2}{3}=(3+2)+\left(\frac{2}{7}+\frac{2}{3}\right)=5+\left(\frac{6}{21}+\frac{2}{21}\right)=5+\frac{20}{21}=5 \frac{20}{21}$

2. Pengurangan pada bilangan pecahan

Bilangan pecahan dapat dikurangi dengan bilangan pecahan yang lain jika bilangan pecahan tersebut memiliki penyebut yang 
sama. Jika penyebutnya berbeda maka harus disamakan terlebih dahulu dengan cara mencari KPK dari penyebut tersebut.

Dapat ditulis :

$\frac{a}{b}-\frac{c}{d}=\frac{a d}{b d}-\frac{b c}{b d}=\frac{a d-b c}{b d}$

a. Pengurangan dua pecahan berpenyebut sama

Pengurangan pecahan yang memiliki penyebut sama, dilakukan dengan cara mengurangkan pembilang-pembilangnya dan berpenyebut tetap.

\section{Contoh:}

1) $\frac{4}{7}-\frac{3}{7}=\frac{4-3}{7}=\frac{1}{7}$

2) $3 \frac{4}{5}-\frac{1}{5}=3+\left(\frac{4-1}{5}\right)=3 \frac{3}{5}$

3) $4 \frac{7}{9}-1 \frac{5}{9}=(4-1)+\left(\frac{7}{9}-\frac{5}{9}\right)=3+\frac{2}{9}=3 \frac{2}{9}$

b. Pengurangan dua pecahan berpenyebut tidak sama

Langkah pertama yang dilakukan adalah menyamakan penyebut-penyebutnya terlebih dahulu, yaitu dengan cara menentukan KPK-nya. Pembilang disesuaikan nilainya dengan cara mengalikan dengan KPK dari dua penyebut tadi. Selanjutnya, kurangkan pembilang-pembilangnya dan penyebut tetap.

Contoh:

1) $\frac{3}{5}-\frac{1}{4}=\frac{12}{20}-\frac{5}{20}=\frac{12-5}{20}=\frac{7}{20}$

2) $3 \frac{3}{7}-\frac{1}{4}=3+\left(\frac{3}{7}-\frac{1}{4}\right)=3+\left(\frac{12}{28}-\frac{7}{28}\right)=3+\frac{5}{28}=3 \frac{5}{28}$

3) $5 \frac{3}{8}-3 \frac{1}{4}=(5-3)+\left(\frac{3}{8}-\frac{1}{4}\right)=2+\left(\frac{3}{8}-\frac{2}{8}\right)=2+\frac{1}{8}=2 \frac{1}{8}$

3. Perkalian pada bilangan pecahan

a. Perkalian bilangan asli dengan pecahanan 
Perkalian pecahan seperti ini, dapat dilakukan dengan cara mengalikan bilangan asli dengan pembilang pecahan sedangkan penyebutnya tetap.

Contoh:

1) $3 \times \frac{2}{7}=\frac{3 \times 2}{7}=\frac{6}{7}$

2) $\frac{4}{5} \times 3=\frac{4 \times 3}{5}=\frac{12}{5}=2 \frac{2}{5}$

b. Perkalian dua pecahan

Perkalian dua pecahan biasa dilakukan dengan cara mengalikan pembilang dengan pembilang dan penyebut dengan penyebut.

Contoh:

1) $\frac{4}{7} \times \frac{2}{5}=\frac{4 \times 2}{7 \times 5}=\frac{8}{35}$

2) $\frac{5}{6} \times \frac{4}{7}=\frac{5 \times 4}{6 \times 7}=\frac{20}{47}=\frac{10}{21}$

c. Perkalian pecahan campuran

Semua pecahan campuran harus diubah ke bentuk pecahan biasa terlebih dahulu, selanjutnya dilakukan perkalian.

Contoh:

1) $2 \frac{2}{3} \times \frac{4}{7}=\frac{8}{3} \times \frac{4}{7}=\frac{32}{21}=1 \frac{11}{21}$

2) $1 \frac{1}{4} \times 2 \frac{3}{5}=\frac{5}{4} \times \frac{13}{5}=\frac{65}{20}=3 \frac{5}{20}=3 \frac{1}{4}$

d. Perkalian berbagai bentuk pecahan

1) $0,5 \% \times \frac{4}{9}=\frac{1}{2} \times \frac{4}{9}=\frac{4}{18}=\frac{2}{9}$

2) $\frac{3}{8} \times 20 \%=\frac{3}{8} \times \frac{1}{5}=\frac{3}{40}$

4. Pembagian pada bilangan pecahan

Bilangan pecahan $\frac{a}{b}$ dapat dibagi dengan pecahan yang lain $\frac{c}{d}$ dengan cara mengalikan bilangan pecahan $\frac{a}{b}$ dengan bilangan pecahan $\frac{d}{c}$, (dimana $\frac{d}{c}$ adalah kebalikan dari bilangan pecahan $\frac{c}{d}$ ). 
a. Pembagian pecahan dengan bilangan asli atau sebaliknya

Cara pembagian pecahan yaitu dengan mengalikan bilangan yang dibagi dengan kebalikan dari bilangan pembagi.

Contoh:

1) $4: \frac{3}{7}=4 \times \frac{7}{3}=\frac{28}{3}=9 \frac{1}{3}$

2) $\frac{5}{6}: 3=\frac{5}{6} \times \frac{1}{3}=\frac{5}{8}$

b. Pembagian dua pecahan

Contoh:

1) $\frac{5}{8}: \frac{2}{3}=\frac{5}{8} \times \frac{3}{2}=\frac{15}{16}$

2) $\frac{4}{5}: \frac{3}{7}=\frac{4}{5} \times \frac{7}{3}=\frac{28}{15}=1 \frac{13}{5}$

c. Pembagian pecahan campuran

Semua pecahan campuran harus diubah ke bentuk pecahan biasa terlebih dahulu, selanjutnya dilakukan operasi pembagian. Contoh:

1) $2 \frac{1}{6}: \frac{4}{7}=\frac{13}{6}: \frac{4}{7}=\frac{13}{6} \times \frac{7}{4}=\frac{91}{24}=3 \frac{19}{24}$

2) $1 \frac{1}{5}: 2 \frac{2}{3}=\frac{6}{5}: \frac{8}{3}=\frac{6}{5} \times \frac{3}{8}=\frac{18}{40}=\frac{9}{20}$

d. Pembagian berbagai bentuk pecahan

Contoh:

1) $0,35: \frac{1}{5}=\frac{35}{100}: \frac{1}{5}=\frac{35}{100} \times \frac{5}{1}=\frac{175}{100}=1 \frac{3}{4}$

2) $\frac{3}{4}: 20 \%=\frac{3}{4}: \frac{1}{5}=\frac{3}{4} \times \frac{5}{1}=\frac{15}{4}=3 \frac{3}{4}$

\section{Menentukan Nilai Pecahan}

1. Nilai Pecahan dari Suatu Bilangan

Nilai pecahan dari suatu bilangan diperoleh dengan cara mengalikan pecahan dengan bilangan tersebut.

Contoh:
a. Hitunglah nilai $\frac{3}{4}$ dari 120
b. Hitunglah nilai $5 \%$ dari 200 Jawab:
Jawab: 
$\frac{3}{4} \times 120=\frac{3 \times 120}{4}=\frac{360}{4}=90 \quad 5 \% \times 200=\frac{5}{100} \times 200=\frac{1.000}{100}=10$

Jadi, nilai $\frac{3}{4}$ dari 120 adalah 90 Jadi, nilai 5\% dari 200 adalah 10

2. Nilai pecahan dari suatu kuantitas tertentu

Bilangan pecahan dalam bentuk desimal sering digunakan untuk menyatakan suatu keadaan. Nilai pecahan dari suatu bilangan sering digunakan dalama kehidupan sehari-hari.

Contoh :

Ibu membeli $2 \frac{2}{3}$ lusin sendok makan dan $\frac{1}{4}$ gros piring di pasar.

Berapakah jumlah sendok dan piring yang dibeli ibu?

Jawab:

Sendok makan $=2 \frac{2}{3} \times 12=\frac{8}{3} \times 12=\frac{96}{3}=32$ buah

Piring $=\frac{1}{4} \times 144=\frac{144}{3}=36$ buah

Banyak barang $=32+36$

$$
=68 \text { buah }
$$

Jadi, jumlah sendok dan piring yang dibeli ibu adalah 68 buah.

\section{B. Lingkaran}

Lingkaran adalah tempat kedudukan titik-titik yang berjarak sama terhadap titik tertentu. Titik tertentu dinamakan pusat dan dan jarak tertentu dinamakan jari-jari lingkaran.

Unsur-unsur lingkaran yaitu :

1. Jari-jari lingkaran

2. Diameter

3. Busur lingkaran

4. Juring Lingkaran

5. Tembereng

6. Apotema 
Rumus Lingkaran yaitu :

a. Keliling lingkaran

$\mathbf{K}=\pi d=\mathbf{2} \pi \mathbf{r}$

Keterangan: $\mathrm{K}=$ Keliling lingkaran

$$
\begin{aligned}
& r=\text { Jari-jari } \\
& \mathrm{d}=\text { Diameter } \\
& \pi=22 / 7 \text { atau } 3,14
\end{aligned}
$$

b. Luas lingkaran

$\mathrm{L}=\pi \mathrm{r}^{2}$

Keterangan :

$r=$ Jari-jari

$\pi=22 / 7$ atau 3,14

\section{Tabung}

Tabung adalah sebuah ruang 3 dimensi yang dibentuk oleh 2 buah lingkaran identik yang sejajar dan sebuah persegi panjang yang mengelilingi kedua lingkaran tersebut.

\section{Ciri-ciri tabung:}

1. Memiliki 4 rusuk

2. Selimut tabung

3. Rusuk tabung

\section{Unsur-unsur tabung:}

1. Ada dua sisi,yaitu sisi alas dan sisi atas

2. Jarak alas dan tutup disebut tinggi tabung

3. Jarring-jaring lingkaran dari alas dan tutup adalah AB

4. Selimut tabung merupakan bidang lengkung.

\section{Sifat-sifat tabung:}

1. Bidang alas dan bidang atas berupa lingkaran dengan jari-jari yang sama

2. Tinggi tabung adalah jarak antara titik pusat lingkaran alas dan titik pusat lingkaran atas. 


\section{Jaring-jaring tabung:}

1. Selimut tabung yang berupa persegi panjang dengan panjang = keliling alas tabung $=2 \pi \mathrm{r}$ dan lebar $=$ tinggi tabung $=\mathrm{t}$

2. Dua buah lingkaran berjari-jari.

\section{Rumus tabung :}

1. Luas tabung

Luas selimut tabung $=$ keliling alas $\mathrm{x}$ tinggi tabung

$$
\begin{aligned}
& =2 \pi \mathrm{rx} \\
& =2 \pi \mathrm{rt}
\end{aligned}
$$

2. Volume tabung

Volume tabung $=2 \pi \mathrm{r} 2 \mathrm{t}$ 


\section{BAB III}

\section{PENUTUP}

\section{A. Kesimpulan}

Bilangan pecahan adalah bilangan yang terdiri dari pembilang dan penyebut yang menggambarkan bagian dari keseluruhan yang dilambangkan dengan $\frac{a}{b}$. Ada beberapa jenis bilangan pecahan biasa, pecahan campuran, pecahan desimal, dan persen. Operasi hitung pada bilangan pecahan terdiri dari penjumlahan pada bilangan pecahan, pengurangan pada bilangan pecahan, perkalian pada bilangan pecahan dan pembagian pada bilangan pecahan.

Lingkaran adalah tempat kedudukan titik-titik yang berjarak sama terhadap titik tertentu. Titik tertentu dinamakan pusat dan dan jarak tertentu dinamakan jari-jari lingkaran.

Tabung adalah sebuah ruang 3 dimensi yang dibentuk oleh 2 buah lingkaran identik yang sejajar dan sebuah persegi panjang yang mengelilingi kedua lingkaran tersebut.

\section{B. Saran}

Demikian yang dapat kami paparkan mengenai materi yang menjadi pokok bahasan dalam makalah ini, Tentu masih banyak kekurangan dan kelemahannya karena terbatasnya pengetahuan dan kurangnya rujukan atau referensi yang ada hubungannya dengan judul makalah ini. Penulis banyak berharap para pembaca yang budiman memberikan kritik dan saran yang membangun kepada penulis demi sempurnanya makalah ini dan makalah-makalah di kesempatan berikutnya. Semoga makalah ini berguna bagi penulis khususnya juga para pembaca yang budiman pada umumnya. 


\section{DAFTAR PUSTAKA}

Jusmawati,S.Pd., M.Pd. Matematika Dasar. Makassar : 2004

Jusmawati, 2021. Model-Model Pembelajaran Inovatif di Sekolah Dasar. Yogyakarta : Samudera Biru

Jusmawati, Satriawati, R. Irman. 2018. Strategi Belajar Mengajar. Makassar: Rizky Artha Mulia

Jusmawati, Eka Fitriana HS, 2019. Manajemen Kelas. Banten : CV.AA.Rizky

Purnomosidi. 2018. Senang Belajar Matematika. Jakarta : Kementrian Pendidikan dan Kebudayaan.

Slamet Riyaldi. 2008. Persiapan Ujian Nasional Matematika. Bandung : Grafindo Media Pratama.

Gunanto, Dhesy. 2006. Matematika Untuk SD/MI Kelas IV. Jakarta : Gelora Aksara Pratama.

Kuliah, Mata and S.Pd Jusmawati. "Pecahan Campuran".

Aji, M. Mukti dan Henny Listyastuti. 2003. Matematika. Klaten: Intan Pariwara. 